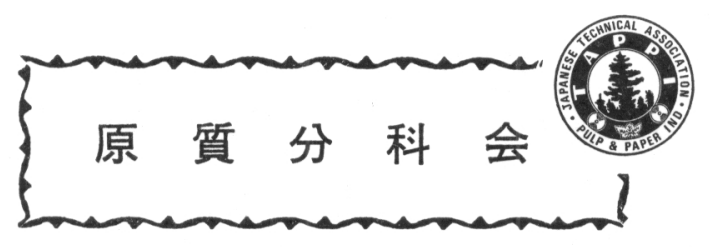

\title{
Pulping Session
}

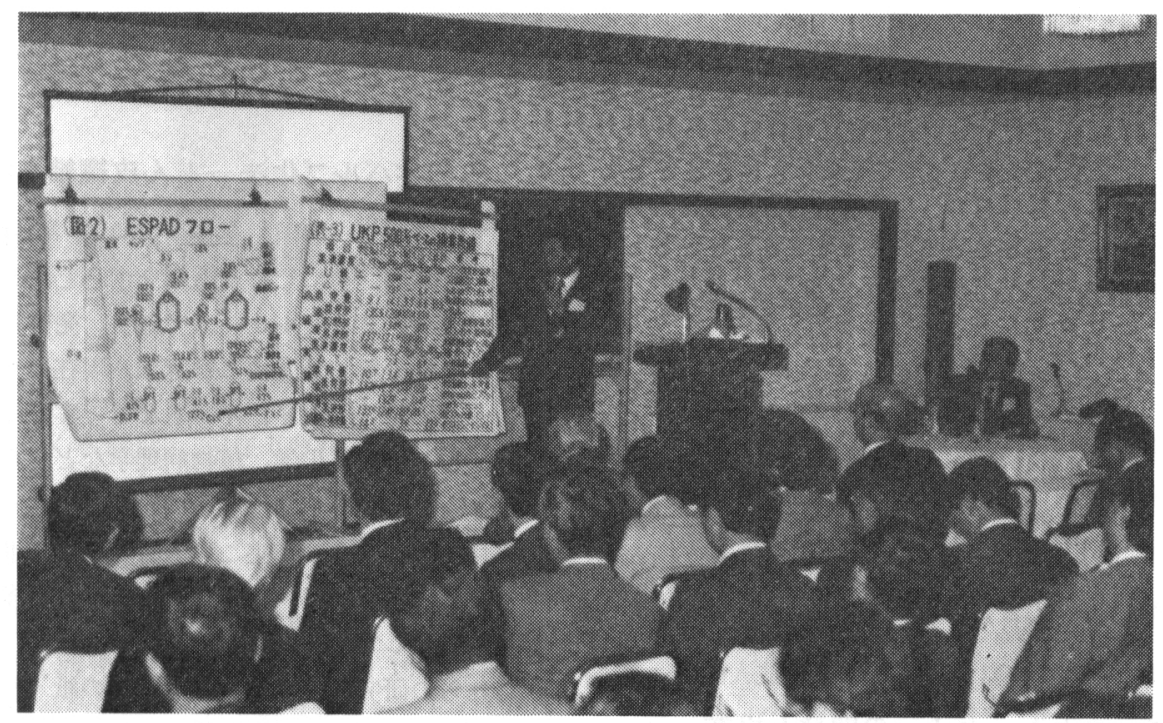

原質分科会会場

原質分科会は，米子国際ホテル白鳥の間にて，10月 14 日午後 1 時より予定通り開催された。参加希望者が 多く, 会場の収容能力を大幅に上回るため, 教室式机 配置が不可能になる程の盛況であり, 出席者は約 130 名を数えた。

司会者より, あいさつと分科会の進め方について説 明があったのち講演に入った。講演は 4 件で内 2 件は $\mathrm{KP}$ 工場における最新設備の操業経験とその評価を示 したもの，1 件は機械メーカーによる新設備の紹介， 残る 1 件は生化学パルプ化法の研究報告であった。各 講師は, それぞれの演題について, 貴重な経験と豊富 な知識を開陳され, 参加者に深い感銘を与えた。特に, 2 工場の操業経験に関する講演は, 省資源, 省エネル ギーの重要性と緊急性からみて, 我々に新しい眼を開 かせたものといえよう。

講演に引続き, 東京大学の中野教授をパネルリー

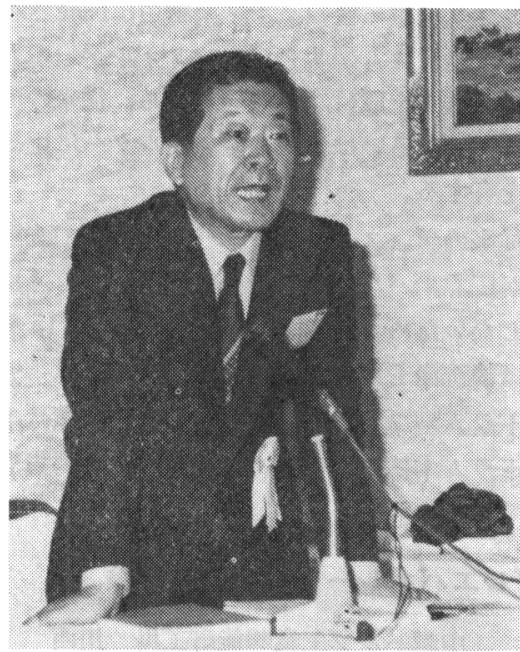

司会者下田氏(王子) 
ダーとして, 紙パルプ資源問題に関するパネルディス カッションが行われた。討議に熱が入り，やや定刻を 過ぎたが，無事に分科会のスケジュールを終了した。

以下に各講演とパネルディスカッションの要旨を述 ベる。

\section{1. $\mathrm{V}$ 型チップスクリーンの性能と操業経験}

王子製紙㑣江別工場 伊丹 明敬氏

V 型スクリーンはチップの厚みを一定厚以下に抑え る装置であり, 蒸解工程において均一な薬液浸透によ るかす率の減少と原木歩留の向上を目的としている。

王子製紙江別工場では，蒸解液の浸透不足によるか 寸率の増加と結束緎維によるちりトラブルの問題があ ったため，国内では初めてV型スクリーンを導入した。

設備は, $\mathrm{V}$ 型スクリーン，メータリングビン， ス トーントラップ, チップスライサーの主要機器とこれ らを継ぐコンベャより構成されており，56 年 7 月か らほぼ順調に稼動しており，所期の成果をあげてい る。

1）未晒カッパー価のアップが可能となり原木歩留 が向上した。

2) ノットかすが N.L とも $60 \sim 70 \%$ 減少し, 連 釜・未晒スクリーンの操業が安定した。

3） パルプ中のちりが $\mathrm{N} \cdot \mathrm{B} \cdot \mathrm{KP}$ で $50 \%$, L・ $\mathrm{B} \cdot \mathrm{KP}$ で $30 \%$ 減少した。また，パルプ強度も大幅に 向上した。

\section{S 型ディスクシックナーの開発と操業}

清朝機械㑣 高橋 満雄氏

清朝機械の S 型ディスクシックナーは精選スクリー ンおよびクリーナー後のパルプ濃縮用に開発されたシ ックナーで，ドラム型サクションフィルターのドラム 表面にディスクを取付けた構造をもち, 従来のディス クフィルターあるいはドラム型フィルターに比べ優れ た特徴を有する。

1）従来のディスクフィルターに比較して洗浄脱水 ゾーンが広く, パルプマットのはぎ取りにシャワー水 は使用しないため, 出口パルプ濃度が高く $15 \%$ 以上 あり, 置換洗浄も可能。

2) ドラム型フィルターに対して据付面積は半分で 済み，ドラム本体およびレパルパーの消費馬力も少な w。

\section{3. プレエパポレーターの探業経験}

中越パルプ工業㑛能町工場 川西 蔽氏 プレエバポレーターとは連続蒸解釜における抽出黒
液のフラッシュサイクロンおよびガスコンデンサー系 統に装置したプレート型エバポレーターで, 黒液の予 備濃縮による濃縮工程の節蒸気と高-低 BOD ドレン の分離による環境保全を目的としており，ESPAD シ ステムと称している。

中越パルプ能町工場では, 国内で初めて本システム を採用し，57年 2 月より順調に稼動し，ほぼ計画通り の結果を得ている。

1）黑液固型分濃度は $2 \%$ 向上。スチーミングベッ セルでの蒸気増加とガスコンデンサーでの温水取得量 の減少は実操業において見られず, トータルエネル ギーとしての節減となった。

2）抽出黒液中の纎維分によるプレエバポレーター での u 值低下はみられない。

\section{4. 生化学パルプ化法一じん皮織雓を中心に一}

四国工業技術試験所 小林 良生氏 非木材纎維, 特にじん皮繊維を中心とするパルプ化 は, 対象がペクトセルロースであり, 発酵精練といわ れる微生物分解法が過去には麻類, 現在でもケナフ, ジュートに対してタイ, インドなどで実際に行われて いる。また, 食品化学, 植物病理学などからの研究的 蓄積も多い。

小林氏らは, 1980 年来この分野の研究を進めており, その研究経過を 50 にのぼる引理斜献 と数多くのスラ イドを駆使して報告された。

これらの研究的アプローチは現在の紙パルプの主流 である木材リグニンの微生物分解にも貴重な示唆を与 えるものと思われる。

\section{5.「将来の紙パルプ資源問題と技術対応」}

座長 東京大学農学部 中野 準三氏 パネラー (アイウエ順)

梸日本紙パルプ研究所 浅岡 宏氏 株丸紅物資本部パルプ部 粟村 格治氏 東京農工大学農学部 大江礼三郎氏 工業技術院四国工業試験所 小林 良生氏

王子製紙俐林木育種研究所 千葉 茂氏

まず，座長の中野氏より，8 月末に訪れた米・加で の状況報告があった。「紙の消える日」に対する反応 は一般研究員にはあまりなかったが, 北米では大学と 産業界の共同研究が進んでおり, 例えば, ブラックス プルースの值上りに対抗してジャックパインで MP化 を行う技術, あるいは KP に代わるパルプ化法として 電力の安いカナダでは CPMP が注目されているとい った問題提起がなされた。 


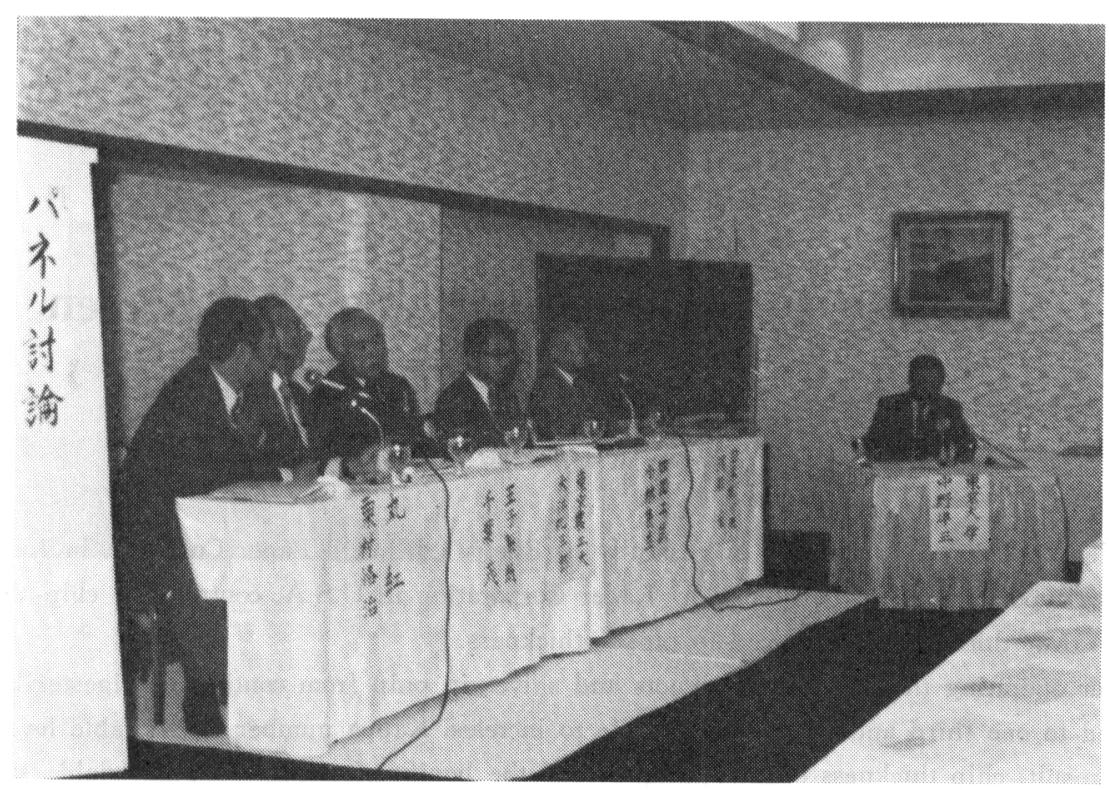

パネル討論（右端はリーダー東大・中野教授）

次に各パネラーとの質疑に移り,「紙の需要 2,500 万 $\mathrm{t}$ 時代のくる時期」（現在 1,800 万 $\mathrm{t}$ ), 「資源問題 について各人の立場からの意見」,「今後の技術対応」 等について貴重な御発言があった。その一部を以下に 紹介する。

\section{日本紙パ研 浅岡氏}

2,500 万 $\mathrm{t}$ 時代は予測研の予想通り 1993 年にくる と思う。資源の主体はやはり森林資源であり, 制限さ れた資源をらまく使いこなす技術を確立したり，例え ば，南洋材のベッセルの分離と改質，あるいはリグニ ンの有効利用といった技術開発が重要である。

\section{丸紅 栗村氏}

2,500 万 $\mathrm{t}$ 時代は自分の経験から考えると難しいか もしれないが, ぜひ達成したいものだ。海外資源につ いていえば，現在はチップの $42 \%$ ，パルプの $22 \%$ を 輸入に依存している。しかし，今後 5 年閒は何の心配 もいらず，日本は欲しいものだけ輸入できる。将来は 量の確保はできるが, 低品質のチップと古紙が増加す るだろら。従って, 現在こそ, その対応策を真剣に考 えるべき時期である。

東京農工大 大 江氏 2,500万 $\mathrm{t}$ 時代は 1993 年とみるが，輸入がふえれ
ば意味がなく，いかに生産を伸していくかが課題。古 紙利用についていえば，1974年からの新聞用紙への 使用増が発端となり年々増加している。回収率は現在 47〜 48\%で50\%が限界といわれており，新たな技術 的進展が望まれる。

\section{工業技術院 小 林氏} 米国人並の消費パターンになれば，2,500 万 $\mathrm{t}$ 時代 は $20 \sim 30$ 年先にくると思ら。非木材の立場からいえ ば，日本の基礎研究のレベルは低い。オーストラリア ではパガス (さとらきび) の利用技術が進んでおり, ユーカリと特性が似ている。米国では成長が早く, 可 能性を秘めるケナフをとりあげ，3,000 種以上のテス 卜を行い，組織的，長期的に検討している。

\section{王子製紙 千 葉氏}

2,500 万 $\mathrm{t}$ 時代は自分の立場からは，こない方があ りがたい。国内の森林資源についていえば，今後人工 林の蓄積の成果があらわれ，輸入材の量はふえるが比 率は低下傾向となるだろう。ただし，国内の広葉樹資 源は不足しているので, バイオテクノロジーを使って 熱帯性広葉樹資源の開発を検討したい。使用側からも どのような樹種を植えたらよいのかフィードバックが 欲しい。

（王子・下田宗憲） 